\title{
Analisis Kemampuan Menulis Makalah Mahasiswa Baru PGSD Universitas Mataram
}

\author{
Arif Widodo $^{1}$, Abdul Kadir Jailani ${ }^{2}$, Setiani Novitasari ${ }^{3}$, Deni Sutisna ${ }^{4}$, \\ Muhammad Erfan ${ }^{5}$ \\ Prodi Studi PGSD FKIP Universitas Mataram ${ }^{1,2,3,4,5}$ \\ arifwidodo@unram.ac.id ${ }^{1}$, jhelan2013@unram.ac.id ${ }^{2}$, \\ setianinovitasari@unram.ac.id ${ }^{3}$, denisutisna@unram.ac.id ${ }^{4}$, \\ muhammaderfan@unram.ac.id ${ }^{5}$
}

\begin{abstract}
Abstrak
Menulis adalah salah satu keterampilan penting yang harus dikuasai oleh mahasiswa. Penelitian ini bertujuan untuk mendeskripsikan kemampuan menulis mahasiswa baru di Program Studi PGSD Universitas Mataram. Jenis penelitian yang digunakan adalah kualitatif dengan pendekatan deskriptif. Pengumpulan data dilakukan dengan observasi, kuesioner, wawancara, dan dokumentasi. Hasil penelitian menunjukkan bahwa kemampuan menulis makalah mahasiswa masih sangat rendah, tingkat plagiarisme sangat tinggi dan teknik penulisan makalah tidak sesuai dengan pedoman. Kesulitan yang paling dihadapi oleh mahasiswa dalam menulis makalah adalah kesulitan dalam menemukan referensi dan tidak mengetahui teknik menulis. Faktor-faktor yang menyebabkan kesulitan dalam menulis makalah termasuk minat baca yang rendah, instruksi menulis yang tidak jelas, keingintahuan mahasiswa yang rendah, dan rendahnya motivasi mahasiswa dalam menulis.
\end{abstract}

Kata kunci: Menulis, Makalah, Mahasiswa Baru, PGSD 


\section{PENDAHULUAN}

Menulis merupakan salah satu dari literasi dasar yang wajib dikuasai dalam menghadapi tantangan abad 21. Terlebih lagi sebagai seorang mahasiswa menulis merupakan keterampilan yang sangat fundamental untuk dimiliki. Mahasiswa dituntut untuk mempunyai kemampuan menulis karena dalam setiap mata kuliah dosen selalu mewajibkan mahasiswa untuk menulis karya ilmiah, salah satu diantaranya adalah makalah. Menulis makalah menjadi kegiatan rutin yang tidak dapat dipisahkan dalam kehidupan akademik di kampus. Kemampuan menulis makalah merupakan salah satu investasi jangka panjang terutama dalam mempersiapkan tugas akhir mahasiswa. Melalui menulis mahasiswa dapat terlatih untuk menuangkan ide-ide baru kemudian mengembangkanya untuk kemajuan ilmu pengetahuan. Kegiatan menulis pada dasarnya dapat memfasilitasi mahasiswa untuk mengkomunikasikan informasi baru, pengetahuan baru, gagasan baru berdasarkan hasil kajian dan penelitian (Persadha, 2016).

Seringkali dijumpai mahasiswa telat lulus kuliah karena terkendala pada tugas akhir. Hal ini sesuai dengan hasil penelitian Rismen (2015) bahwa banyak mahasiswa yang mengalami kesulitan dalam menyelesaikan skripsi, salah satu indikatornya adalah lamanya waktu bimbingan yang dilalui mahasiswa tersebut. Kesulitan semacam ini salah satunya faktor penyebabnya adalah ketidakmampuan mahasiswa dalam menuliskan ide yang ada dalam pikirannya. Menulis merupakan sebuah proses dalam menuangkan ide atau gagasan ke dalam bentuk tulisan melalui rangkaian kata yang disajikan secara utuh, lengkap dan jelas sehingga mampu menyampaikan secara jelas kepada pembaca apa yang ada dalam pikiran tersebut (Praptanti \& Noorliana, 2017). Keterampilan menulis sebagai salah satu keterampilan berbahasa di dalamnya memiliki berbagai unsur yang sangat kompleks, sehingga tidak semua orang dapat melakukan melakukan aktivitas tersebut dengan baik (Cahyani, 2010).

Ironisnya dengan begitu pentingnya kemampuan menulis tersebut masih banyak dijumpai karya mahasiswa yang hanya copy paste, comot sana comot sini tanpa prosedur pengutipan yang benar. Menulis bagi kebanyakan mahasiswa masih merupakan beban yang sulit untuk diselesaikan. Beberapa hal yang menunjukkan bahwa menulis menjadi beban berat mahasiswa diantaranya: rendahnya partsipasi mahasiswa dalam lomba karya tulis ilmiah, rendahnya publikasi ilmiah mahasiswa, pemanfaatan perpustakaan sebagai ruang baca kurang, lebih suka diberi tugas diskusi daripada menulis, lebih suka menyampaikan aspirasi dengan orasi daripada dengan publikasi artikel dan tulisan mahasiswa kebanyakan hanya berisi teori-teori yang tidak relevan dengan pembahasan atau bahkan jiplakan dari tulisan orang lain (Rahmiati, 2013). Berdasarkan pendapat tersebut tidak mengherankan 
apabila selain skripsi tidak ada lagi karya ilmiah yang dimiliki mahasiswa. Lebih lanjut (Rahmiati, 2013) mengungkapkan bahwa ada beberapa alasan yang disampaikan mengapa mahasiswa tidak menulis diantaranya merasa tidak berbakat, motivasi yang kurang, terkendala waktu, dan sulitnya mencari referensi. Adhikara, Handayani, Jumono, \& Darmansyah (2014) menyatakan bahwa kebanyakan mahasiswa tidak mau menulis karya ilmiah karena rendahnya pengetahuan dan kemampaun dalam pembuatan karya ilmiah tersebut. Oleh karena itu pembiasaan dan latihan tentang penulisan karya ilmiah harus dilakukan sejak dini, salah satunya dengan membiasakan menulis makalah dengan benar. Hal ini sesuai dengan pendapat Halidjah (2015) bahwa keterampilan menulis tidak diperoleh secara alamiah namun harus melalui latihan, berbeda dengan kemampuan menyimak dan berbicara yang dapat diperoleh secara alamiah.

Terdapat beberapa penelitian terdahulu yang mengkaji tentang keterampilan menulis mahasiswa. Hasil penelitian (Yanti, Suhartono, \& Hiasa, 2018) menunjukkan bahwa kemampuan mahasiswa dalam menulis sangat rendah dan ditemukan beberapa karya mahasiswa yang terindikasi plagiat. Penelitian (Pramudiyanti, 2018) menunjukkan bahwa sebagian besar makalah tidak sesuai dengan pedoman penulisan makalah, selain itu mahasiswa juga tidak mampu untuk membuat kalimat penghubung dan menyimpulkan bacaan (parafrase) sehingga ditemukan 100\% isi makalah mahasiswa berupa copy paste dari bacaan yang sudah ada. Kedua penelitian di atas mengkaji mahasiswa secara umum, namun yang akan dikaji dalam penelitian ini adalah kemampuan menulis bagi mahasiswa baru PGSD Universitas Mataram. Mahasiswa baru dijadikan sebagai subyek penelitian dengan alasan kemampuan menulis merupakan keterampilan yang tidak dapat diperoleh secara spontan dan perlu pembiasaan sejak dini. Melalui penelitian ini diharapkan dapat mendeteksi sejak dini masalah penulisan karya ilmiah sehingga menghasilkan saran agar kendala menulis terutama bagi mahasiswa baru dapat terselesaikan. Penelitian ini dilakukan karena berdasarkan hasil pengamatan sebagian besar tugas mahasiswa baru PGSD hanya copy paste dari internet. Menurut (Rahmiati, 2015) konsep plagiarism telah terbangun dalam diri mahasiswa sejak awal ketika pertama kali masuk perguruan tinggi. Berawal dari sini perlu diadakan penelitian apa saja permasalahan yang dihadapi mahasiswa baru dalam menulis makalah sehingga mencari jalan pintas dengan mengambil tulisan orang lain tanpa prosedur yang benar. Masalah utama dalam penelitian ini adalah 1. Bagaimana kemampuan menulis makalah mahasiswa baru. 2. Kesulitan apa saja yang dialami mahasiswa dalam menulis makalah. 3. Faktor apa saja yang menyebabkan mahasiswa baru kesulitan dalam menulis makalah. 


\section{METODE PENELITIAN}

Penelitian ini menggunakan pendekatan kualitatif dengan pendekatan deskriptif. Subyek dalam penelitian ini adalah mahasiswa baru PGSD, Pengumpulan data dilakukan melalui observasi, angket, dokumentasi dan wawancara. Jumlah populasi mahasiswa baru sebanyak 342, namun setelah diberi angket melalui google form sampai batas waktu yang telah ditentukan hanya 107 mahasiswa yang mengisi angket. Angket digunakan untuk mengungkap persepsi, dan motivasi yang menjadi kendala dalam penulisan tugas. Agar dapat menjaring data yang lebih spesifik maka dalam angket tersebut tidak hanya angket tertutup tetapi juga disediakan angket terbuka sehingga mahasiswa dapat membuat jawaban sendiri sesuai dengan keadaan pada dirinya tanpa terpengaruh oleh jawaban yang telah disediakan. Dokumen yang dipakai berupa makalah hasil tulisan mahasiswa baru. Makalah yang dijadikan sampel dalam penelitian ini adalah makalah tugas kelompok pada mata kuliah pengantar pendidikan dengan jumlah 18 makalah. Makalah tersebut kemudian dianalisis dengan berpedoman pada instrument berikut:

Tabel 1. Pedoman Penilaian Menulis Makalah

\begin{tabular}{rrr}
\hline No & \multicolumn{1}{c}{ Aspek Penilaian } & $\begin{array}{c}\text { Skor } \\
\text { Maksimal }\end{array}$ \\
\hline \multicolumn{3}{c}{ Isi gagasan } \\
a. & Orisinalitas makalah, kemampuan mengolah ide/gagasan \\
& $\quad$ dalam bentuk tulisan & 20 \\
& b. & Kemampuan menguraikan latar belakang \\
& c. & Kesesuaian rumusan masalah dengan topik permasalahan \\
& d. & Kesesuaian rumusan masalah dengan tujuan penulisan \\
\hline
\end{tabular}

Organisasi isi

a. Ukuran kertas, kerapian tulisan, tata letak, dan penomoran

2 halaman

b. Kelengkapan bagian makalah

c. Kesesuaian pembahasan dengan materi kuliah

d. Format penulisan makalah

Tata bahasa

a. Penggunaan bahasa Indonesia yang baik dan benar

3

b. Efektivitas kalimat, pemilihan kosa kata

c. Penggunaan EYD 


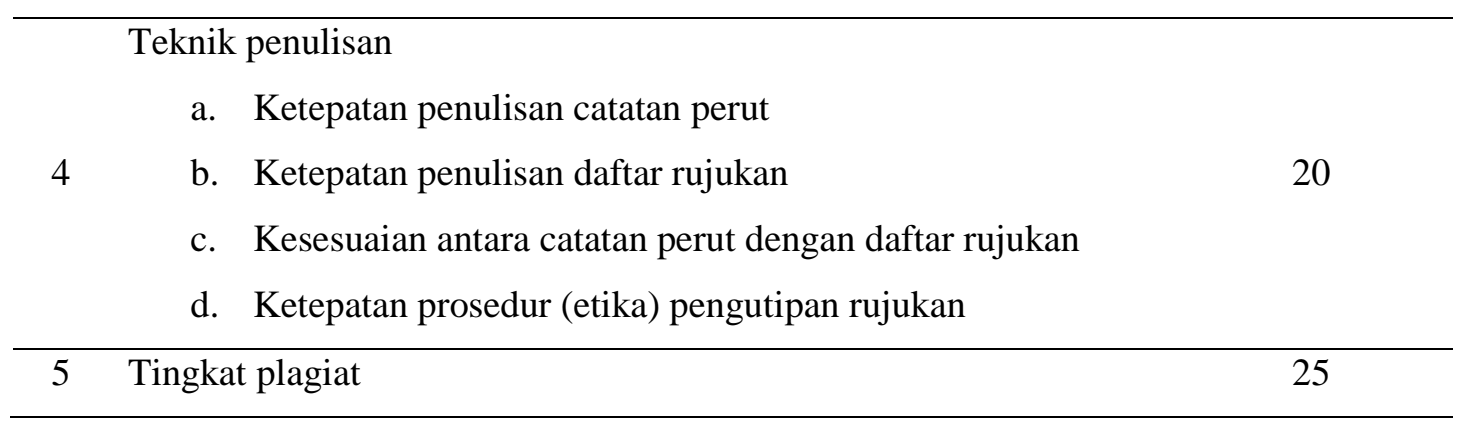

Berdasarkan tabel di atas dapat diketahui bahwa terdapat empat aspek yang dijadikan indikator dalam menilai kualitas makalah mahasiswa yaitu isi gagasan, organisasi isi, tata bahasa, teknik penulisan dan tingkat plagiat. Pemberian skor pada masing-masing aspek tidak sama disesuaikan dengan tingkat kesulitannya. Aspek tingkat plagiat mendapatkan porsi penilaian terbesar karena kejujuran dalam menulis karya ilmiah adalah aspek terpenting yang harus diutamakan. Pemberian skor pada indikator tingkat plagiat berbanding terbalik dengan hasil plagiarism scan report pada aplikasi plagiarism checker. Semakin tinggi tingkat plagiat maka akan semakin rendah skor yang didapatkan. Data yang telah didapatkan dianalisis dengan menggunakan statistik deskriptif kemudian disajikan dalam bentuk tabel dan diagram.

\section{HASIL DAN PEMBAHASAN}

\section{A. Kemampuan menulis makalah mahasiswa baru}

Kemampuan menulis mahasiswa baru dapat dilihat dari kualitas makalah yang telah ditulis oleh mahasiswa. Hasil analisis terhadap 18 makalah mahasiswa baru yang digunakan sebagai tugas pada mata kuliah Pengantar Pendidikan dapat disajikan dalam tabel 2 berikut ini

Tabel 2. Kualitas Makalah Mahasiswa Baru

\begin{tabular}{ccccccc}
\hline & \multicolumn{6}{c}{ Aspek Penilaian } \\
\cline { 2 - 7 } No. & Isi & Organisasi & Tata Bahasa & $\begin{array}{c}\text { Teknik } \\
\text { Penulisan }\end{array}$ & $\begin{array}{c}\text { Tingkat } \\
\text { Plagiat }\end{array}$ & Skor \\
\hline 1 & 18 & 18 & 14 & 9 & 12 & 71 \\
\hline 2 & 17 & 17 & 12 & 7 & 11 & 64 \\
\hline 3 & 17 & 16 & 14 & 5 & 6 & 58 \\
\hline 4 & 13 & 17 & 14 & 6 & 4 & 54 \\
\hline 5 & 18 & 15 & 9 & 5 & 6 & 53 \\
\hline 6 & 17 & 15 & 10 & 4 & 4 & 50 \\
\hline
\end{tabular}




\begin{tabular}{ccccccc}
\hline 7 & 16 & 18 & 11 & 3 & 2 & 50 \\
\hline 8 & 17 & 14 & 13 & 4 & 2 & 50 \\
\hline 9 & 12 & 17 & 11 & 5 & 5 & 50 \\
\hline 10 & 16 & 15 & 11 & 4 & 3 & 49 \\
\hline 11 & 12 & 19 & 12 & 5 & 1 & 49 \\
\hline 12 & 17 & 11 & 12 & 3 & 6 & 49 \\
\hline 13 & 15 & 18 & 10 & 2 & 3 & 48 \\
\hline 14 & 13 & 16 & 13 & 2 & 4 & 48 \\
\hline 15 & 14 & 16 & 12 & 4 & 1 & 47 \\
\hline 16 & 11 & 17 & 13 & 2 & 4 & 47 \\
\hline 17 & 14 & 13 & 14 & 2 & 2 & 45 \\
\hline 18 & 12 & 16 & 12 & 2 & 1 & 43 \\
\hline$\Sigma$ & 269 & 288 & 217 & 74 & 77 & 925 \\
\hline
\end{tabular}

Berdasarkan tabel di atas dapat diketahui bahwa skor tertinggi yang diperoleh mahasiswa adalah 71 sedangkan skor terendah adalah 43. Skor dikatakan baik jika berada pada rentang $>75$, cukup baik jika $50<$ skor $\leq 75$ dan kurang baik jika $\leq 50$. Tabel di atas menunjukkan bahwa pada aspek teknik penulisan dan tingkat plagiasi total skor yang diperoleh mahasiswa lebih rendah jika dibandingkan dengan aspek isi, organisasi dan tata bahasa. Skor ideal untuk aspek isi gagasan sebesar 360 sedangkan skor yang didapatkan 269 atau $74,72 \%$ dari skor yang diharapkan. Pada aspek organisasi isi skor idealnya 360 sedangkan skor yang didapatkan 288 atau $80 \%$ dari skor yang diharapkan. Pada aspek tata bahasa skor idealnya 270 sedangkan skor yang didapatkan 217 atau $80.37 \%$ dari skor yang diharapkan. Total skor pada aspek teknik penulisan sebesar 74 sedangkan skor idealnya 360 atau 20,56\% dari skor yang diharapkan. Pada aspek tingkat plagiasi skor yang didapatkan sebesar 77 sedangkan skor idealnya 630 atau 12,22\% dari skor yang diharapkan. Hal ini menunjukkan bahwa makalah yang telah ditulis oleh mahasiswa baru memiliki tingkat plagiasi yang sangat tinggi dan teknik penulisannya juga tidak sesuai dengan kaidah penulisan karya ilmiah, walaupun pada aspek isi gagasan, organisasi isi dan tata bahasa termasuk dalam kategori baik. Skor yang diperoleh pada masing-masing makalah jika dikategorisasikan menjadi tiga kelompok sesuai dengan kriteria di atas maka akan didapatkan data sebagai berikut: 


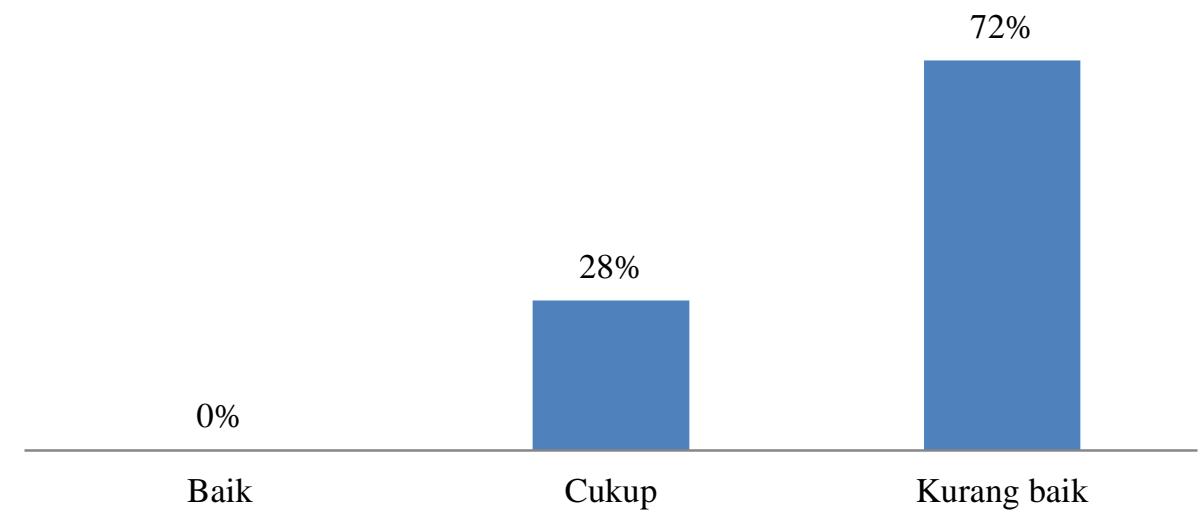

Gambar 1. Kemampuan Menulis Makalah

Gambar di atas menunjukkan bahwa tidak ada makalah mahasiswa yang berkategori baik, makalah dengan kategori cukup sebanyak 28\% sedangkan yang kurang sebanyak $72 \%$. Data tersebut menunjukkan bahwa hanya sedikit makalah mahasiswa yang dinyatakan layak sebagai tugas kuliah. Rendahnya kualitas makalah mahasiswa tersebut disebabkan karena tingginya tingkat plagiasi dan teknik penulisan yang tidak sesuai dengan pedoman penulisan makalah yang baik. Berikut ini disajikan beberapa contoh makalah mahasiswa baru yang terindikasi plagiat:

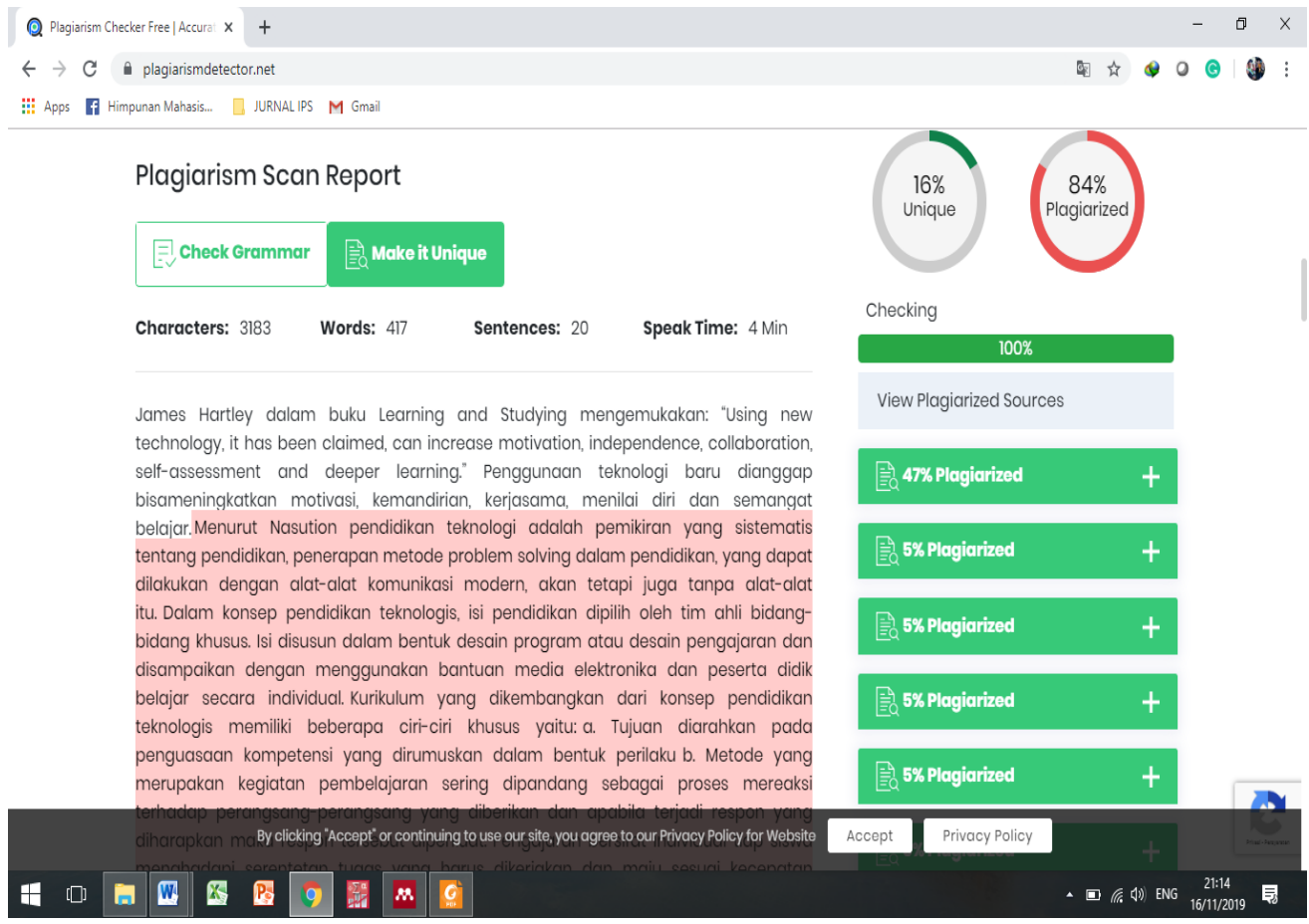

Gambar 2. Kemampuan Menulis Makalah

Plagiarisme makalah tidak hanya terjadi pada bagian isi, bahkan mulai dari kata pengantar makalah mahasiswa telah dimulai dengan tindakan plagiat. Hal ini menunjukkan 
bahwa kemampuan mahasiswa baru dalam merangkai kata-kata menjadi kalimat sangat rendah. Berikut ini disajikan contohnya:

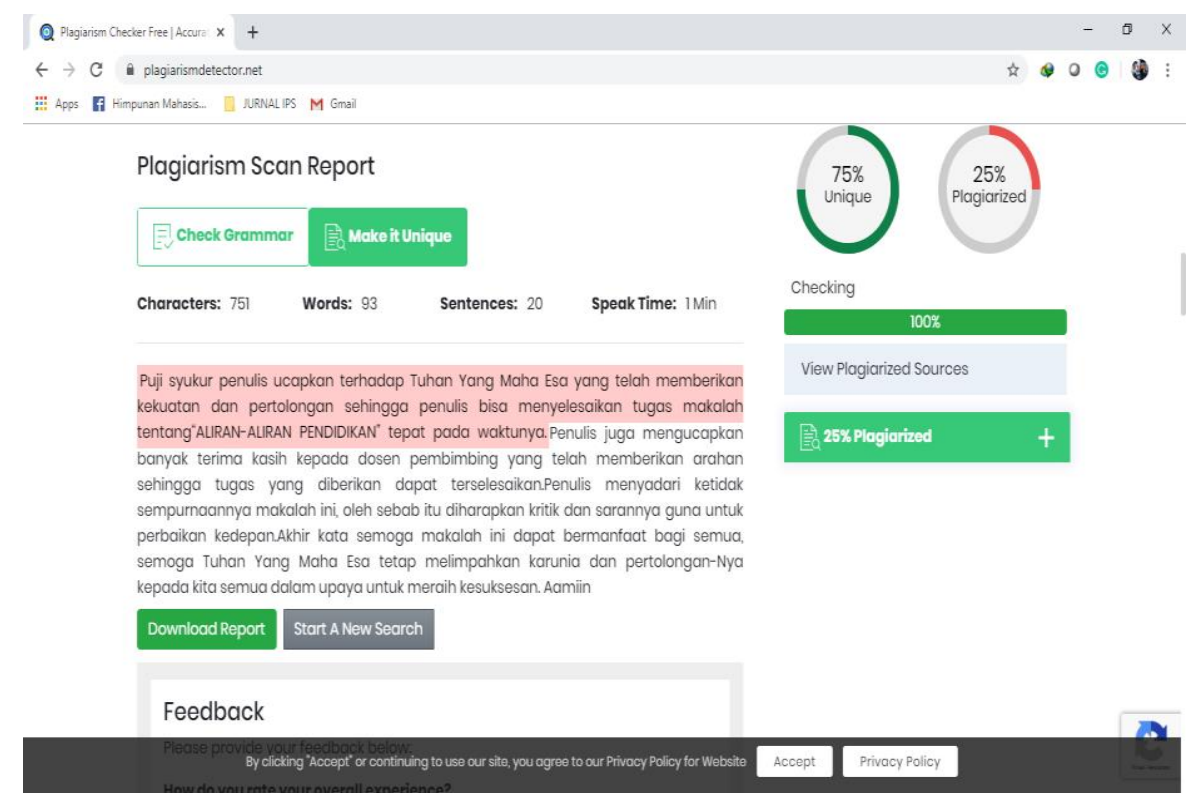

Gambar 3. Contoh bagian kata pengantar yang terindikasi plagiat

Kesalahan pada teknik penulisan yang paling banyak dijumpai adalah dalam penulisan daftar pustaka, cara pengutipan dan ketidaksesuaian antara kutipan dengan daftar pustaka. Berikut ini disajikan salah satu contoh kesalahan dalam menulis daftar pustaka:

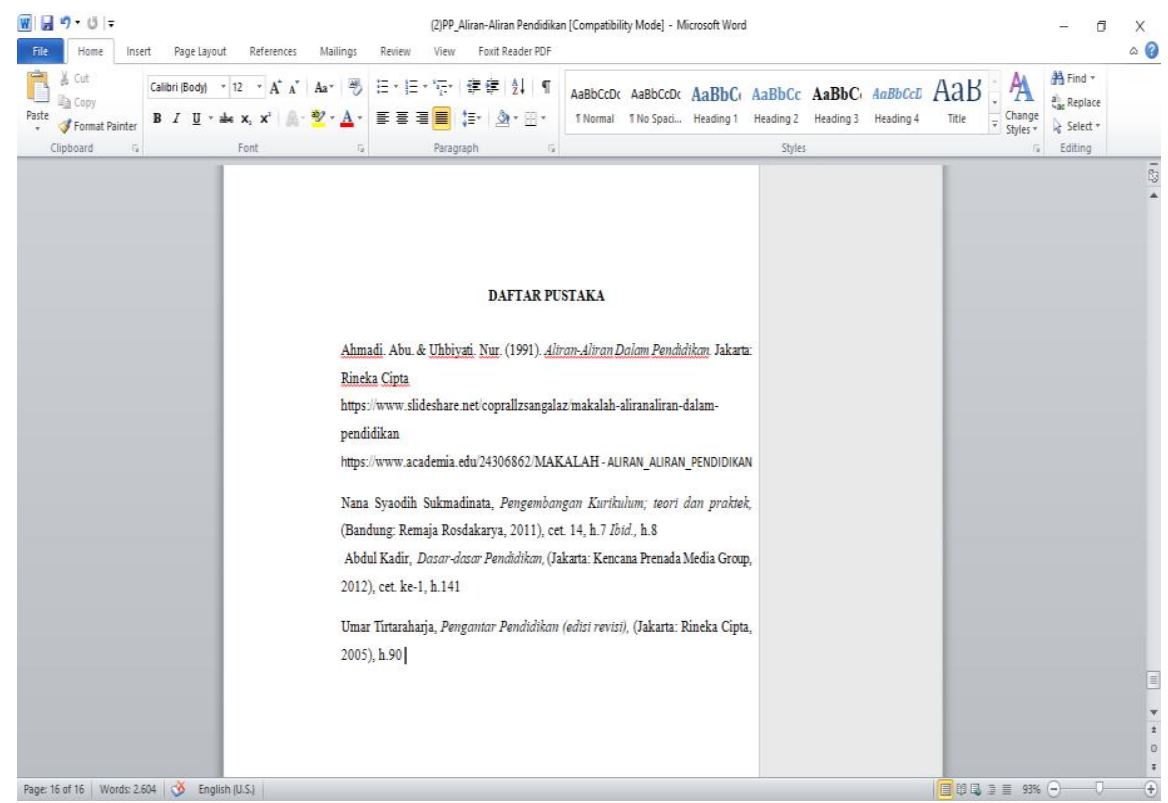

Gambar 4. Contoh penulisan daftar pustaka yang kurang tepat

Berdasarkan angket terbuka yang ditelah diisi oleh 107 responden terdapat $78 \%$ responden yang mengaku mengalami kesulitan dalam menulis makalah, sedangkan sisanya 
22\% mengaku tidak mengalami kesulitan. Berikut ini disajikan perbandingan mahasiswa yang mengalami kesulitan dalam menulis makalah:

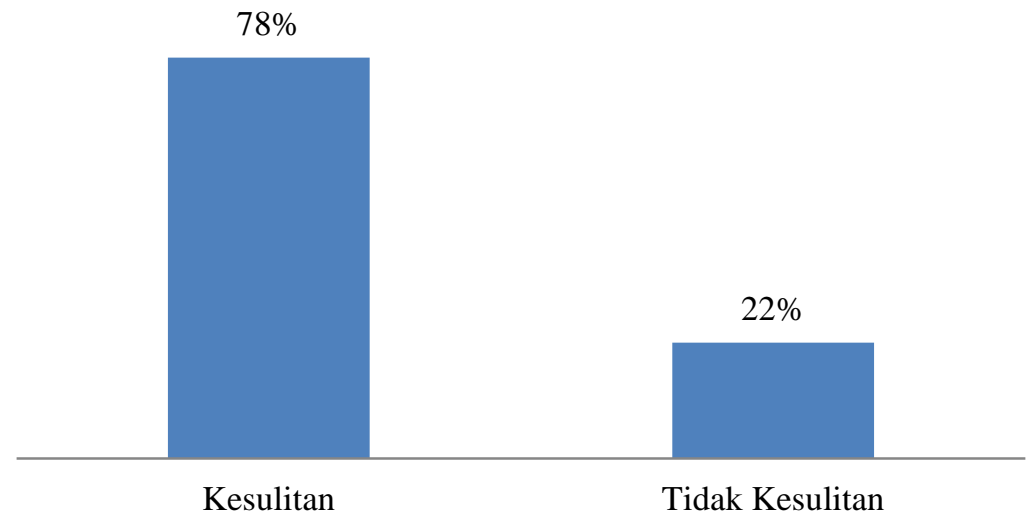

Gambar 5. Jumlah mahasiswa baru yang kesulitan menulis makalah

\section{Jenis kesulitan dalam menulis makalah}

Jenis kesulitan yang dialami mahasiswa baru dalam menulis makalah bervariasi mulai dari kesulitan mencari referensi, kesulitan dalam teknik penulisan, tidak paham dengan teknik penugasan, kurangnya pemahaman materi, kurangnya waktu yang diberikan, terbatasnya sarana, malas baca dan kurangnya kerjasama tim. Berikut ini disajikan jenis kesulitan berdasarkan pengakuan mahasiswa yang diperoleh dari angket terbuka.

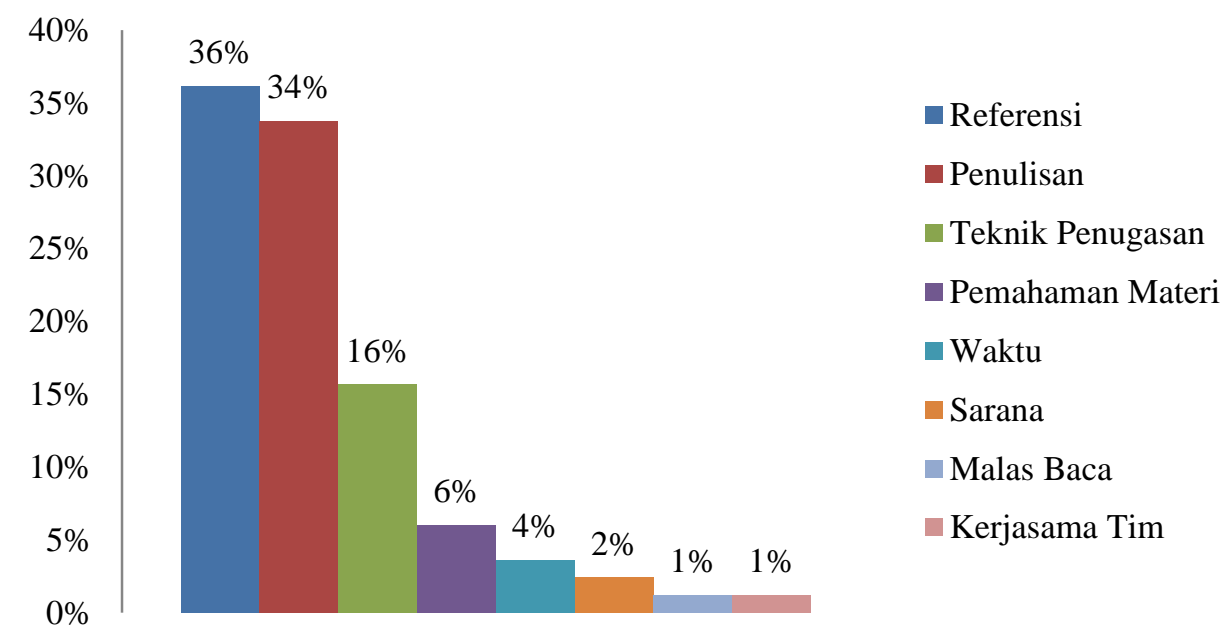

Gambar 6. Jenis kesulitan dalam menulis makalah

Berdasarkan gambar di atas dapat diketahui bahwa kesulitan yang paling banyak dialami mahasiswa baru dalam menulis makalah adalah masalah referensi sebanyak $36 \%$. Mahasiswa mengaku kesulitan mencari referensi yang sesuai dengan tema makalah baik di perpustakaan maupun penelusuran secara online. Kesulitan teknik penulisan makalah menduduki peringkat kedua dengan persentase sebanyak 34\%. Mahasiswa mengaku tidak 
mengetahui prosedur penulisan makalah yang baik, seperti bagaimana mengutip, bagaimana menulis daftar pustaka dan lain-lain. Teknik penugasan menduduki peringkat ketiga dengan persentase sebanyak 16\%. Teknik penugasan berkaitan dengan prosedur dan langkahlangkah penugasan. Mahasiswa mengaku tidak memahami bagaimana cara pengerjaan tugas tersebut, kapan dikumpulkan, dan apakah dikerjakan secara individu atau kelompok. Sebanyak $6 \%$ mahasiswa mengaku tidak memahami materi kuliah yang disampaikan dosen sehingga mengalami kesulitan dalam menulis makalah. Berdasarkan wawancara dengan salah satu mahasiswa mengapa tidak memahami materi kuliah karena jarang memperhatikan materi kuliah yang telah diberikan oleh dosen. Sebanyak 4\% mahasiswa kesulitan menulis makalah karena merasa waktu yang diberikan terlalu mepet. Sarana menjadi alasan dalam menulis makalah dengan persentase sebanyak $2 \%$. Mahasiswa mengaku tidak punya laptop sehingga kesulitan dalam menulis makalah. Malas baca dan kerjasama tim masing-masing mendapatkan persentase $1 \%$ sebagai penyebab sulitnya menulis makalah. Hal ini sesuai dengan hasil wawancara terhadap salah satu mahasiswa yang menyatakan bahwa "akhirakhir ini saya malas baca, sehingga daya nalar saya berkurang”. Terdapat mahasiswa yang mengeluhkan kerjasama tim yang kurang sehingga dalam penulisan makalah menjadi terhambat, mengingat makalah yang harus ditulis adalah tugas kelompok.

\section{Faktor penyebab kesulitan menulis makalah}

Berdasarkan hasil angket terbuka di atas kemudian diberikan angket tertutup untuk mengetahui penyebab kesulitan mahasiswa baru dalam menulis makalah. Berikut ini disajikan jawaban responden berdasarkan hasil angket dengan jumlah 11 pernyataan yang digunakan untuk menjaring data terkait dengan kesulitan menulis makalah.

Tabel 3. Hasil angket responden

\begin{tabular}{l|c|c|c|c|c|c|c|c|c|c|c}
\hline & $\mathbf{1}$ & $\mathbf{2}$ & $\mathbf{3}$ & $\mathbf{4}$ & $\mathbf{5}$ & $\mathbf{6}$ & $\mathbf{7}$ & $\mathbf{8}$ & $\mathbf{9}$ & $\mathbf{1 0}$ & $\mathbf{1 1}$ \\
\hline $\begin{array}{l}\text { Tidak } \\
\text { pernah }\end{array}$ & $29 \%$ & $19 \%$ & $23 \%$ & $2 \%$ & $2 \%$ & $17 \%$ & $24 \%$ & $49 \%$ & $41 \%$ & $11 \%$ & $23 \%$ \\
\hline Jarang & $44 \%$ & $48 \%$ & $31 \%$ & $25 \%$ & $23 \%$ & $44 \%$ & $30 \%$ & $36 \%$ & $42 \%$ & $32 \%$ & $37 \%$ \\
\hline Sering & $23 \%$ & $28 \%$ & $34 \%$ & $65 \%$ & $26 \%$ & $36 \%$ & $35 \%$ & $14 \%$ & $17 \%$ & $46 \%$ & $36 \%$ \\
\hline Selalu & $4 \%$ & $6 \%$ & $12 \%$ & $7 \%$ & $49 \%$ & $3 \%$ & $11 \%$ & $1 \%$ & $0 \%$ & $11 \%$ & $3 \%$ \\
\hline Jumlah & $100 \%$ & $100 \%$ & $100 \%$ & $100 \%$ & $100 \%$ & $100 \%$ & $100 \%$ & $100 \%$ & $100 \%$ & $100 \%$ & $100 \%$ \\
\hline
\end{tabular}

Berdasarkan tabel di atas dapat diketahui bahwa pada aspek pertama dengan pertanyaan "apakah anda membaca referensi dari buku sebelum menulis makalah" sebanyak 29\% responden menjawab tidak pernah, menjawab jarang 44\%, menjawab sering $23 \%$ dan menjawab selalu 4\%. Pada kedua dengan pertanyaan "apakah anda membaca referensi dari jurnal ilmiah sebelum menulis makalah" sebanyak 19\% menjawab tidak pernah, $48 \%$ jarang, $28 \%$ sering dan $6 \%$ menjawab selalu. Pada aspek ketiga dengan pertanyaan "apakah anda 
membaca teknik penulisan karya ilmiah sebelum menulis makalah" sebanyak 23\% menjawab tidak pernah, $31 \%$ jarang, 34\% sering dan 12\% menjawab selalu. Pada aspek keempat dengan pertanyaan "apakah anda mengujungi perpustakaan kampus untuk memenuhi kebutuhan referensi anda" sebanyak 2\% menjawab tidak pernah, $25 \%$ jarang, $65 \%$ sering dan $7 \%$ selalu. Pada aspek kelima dengan pertanyaan "apakah dosen memberikan petunjuk penulisan makalah dengan jelas ketika memberi tugas" sebanyak $2 \%$ menjawab tidak pernah, $23 \%$ jarang, 26\% sering dan 49\% menjawab selalu. Pada aspek keenam dengan pertanyaan "apakah anda memahami teknik penulisan tugas yang diberikan dosen" sebanyak 17\% menjawab tidak pernah, 44\% jarang, 36 sering dan 3\% menjawab selalu. Pada aspek ketujuh dengan pertanyaan "apakah anda bertanya kepada dosen terkait dengan teknik penulisan makalah yang belum dimengerti" sebanyak $24 \%$ menjawab tidak pernah, 30\% jarang, 35\% sering dan 11\% menjawab selalu. Pada aspek kedelapan dengan pertanyaan "apakah anda berdiskusi dengan teman sejawat sebelum menulis makalah" sebanyak $49 \%$ menjawab tidak pernah, 36\% jarang, 14\% sering dan 1\% selalu. Pada aspek kesembilan dengan pertanyaan "apakah anda selalu bersemangat dalam mengerjakan tugas" sebanyak $41 \%$ menjawab tidak pernah, $42 \%$ jarang, $17 \%$ sering dan menjawab selalu $0 \%$. Pada aspek kesepuluh dengan pertanyaan "apakah anda pernah terbebani dengan banyaknya tugas" sebanyak 11\% menjawab tidak pernah, 32\% menjawab jarang, $46 \%$ menjawab sering, dan $11 \%$ menjawab selalu. Pada aspek kesebelas dengan pertanyaan "apakah waktu yang diberikan oleh dosen untuk mengerjakan tugas sudah cukup" sebanyak 23\% menjawab tidak pernah, $37 \%$ jarang, $36 \%$ sering dan $3 \%$ selalu.

Data di atas menunjukkan bahwa kesulitan menulis yang dialami oleh mahasiswa baru disebabkan oleh beberapa hal diantaranya, pertama, minat baca yang rendah. Hal ini dapat ditunjukkan pada indikator yang berkaitan dengan minat baca yaitu item pertanyaan nomor1 sampai dengan nomor 4. Mahasiswa yang selalu membaca buku referensi sebelum menulis makalah hanya sebesar $4 \%$, selalu membaca referensi dari jurnal ilmiah hanya $6 \%$, selalu membaca teknik penulisan karya ilmiah hanya $12 \%$ dan selalu berkunjung ke perpustakaan hanya sebesar 7\%. Kedua, pedoman penulisan yang kurang jelas dari dosen, hal ini dapat dilihat pada item pertanyaan nomor 5 dan 6 yang menunjukkan bahwa hanya $49 \%$ dari dosen yang memberikan petunjuk dengan jelas terkait dengan teknik penulisan makalah. Pada item pertanyaan nomor 5 hanya 3\% mahasiswa yang selalu memahami teknik penulisan yang diberikan tugas. Ketiga, rasa ingin tahu yang rendah dari mahasiswa, hal ini dapat ditunjukkan pada item pertanyaan nomor 7 dan 8 . Pada item nomor tujuh diketahui hanya $11 \%$ mahasiswa yang selalu bertanya kepada dosen jika tidak mengerti teknik penulisan makalah. Pada item nomor 8 hanya $1 \%$ yang selalu berdiskusi dengan teman sejawat 
sebelum menulis makalah. Keempat, motivasi yang rendah. Hal ini dapat dilihat pada item pertanyaan nomor 9 dan 10 yang menunjukkan bahwa tidak ada mahasiswa yang mengaku bersemangat mengerjakan tugas dan 57\% menganggap tugas sebagai beban. Kelima, waktu. Hal ini dapat dilihat pada item pertanyaan nomor 11 yang menunjukkan bahwa sebanyak $23 \%$ mahasiswa merasa waktu yang diberikan dosen dalam menulis makalah masih kurang.

Berdasarkan data penelitian dapat ditemukan beberapa hal diantaranya kualitas tulisan makalah mahasiswa baru masih rendah. Rendahnya kualitas dikarenakan tingginya tingkat plagiasi dan penulisan makalah yang tidak sesuai ketentuan penulisan karya imliah. Hal ini sesuai dengan hasil penelitian (Yanti et al., 2018) yang menunjukkan bahwa secara umum kemampuan mahasiswa dalam menulis sangat rendah dan ditemukan beberapa karya mahasiswa yang terindikasi plagiat. Kejujuran dalam menyusun makalah sangat penting, plagiarisme adalah tindakan yang sangat tidak terpuji. Plagiasi adalah tindakan kecurangan akademis dengan mengambil buah pikiran orang lain, melakukan klaim kemudian mempublikasikan sebagai hasil karyanya (Hariri \& Pradana, 2019). Salah satu cara dalam mengindari plagiasi adalah dengan mencantumkan daftar pustaka atau sumber rujukan yang digunakan (Widiastuti, 2019). Ketidaktahuan mahasiswa terhadap teknik penulisan makalah juga mendorong mahasiswa melalukan tindakan plagiasi. Mahasiswa menganggap bahwa mengambil tulisan orang lain tanpa merujuk adalah sesuatu yang dibenarkan seperti membuat makalah pada waktu SMA. Kondisi seperti ini tidak baik jika tidak segera ditangani, mengingat apa yang mereka lakukan akan menjadi kebiasaan yang buruk. Kesalahan penulisan paling banyak terkait dengan penulisan daftar pustaka, cara mengutip dan ketidaksesuaian antara catatan perut dengan daftar rujukan, bahkan terdapat beberapa makalah yang dalam teks melakukan pengutipan tetapi dalam daftar rujukan tidak dicantumkan.

Kemampuan mahasiswa dalam memahami bacaan juga sangat rendah. Hal ini sesuai dengan penelitian (Pramudiyanti, 2018) yang menunjukkan bahwa selain makalah yang tidak sesuai dengan prosedur penulisan terdapat temuan yang mengindikasikan bahwa mahasiswa tidak mampu untuk membuat kalimat penghubung atau menyimpulkan informasi dari sebuah bacaan (parafrase) sehingga ditemukan 100\% isi makalah mahasiswa berupa copy paste dari bacaan yang sudah ada. Ketidakmampuan mahasiswa dalam mengolah kalimat tidak hanya pada bagian isi saja, bahkan pada bagian pengantar saja sudah diawali dengan mencomot tulisan orang. Hal ini mengindikasikan bahwa kemampuan mahasiswa dalam mengolah katakata berdasarkan apa yang telah dibaca masih sangat kurang. Penulis pemula kebanyakan mengalami kesulitan dalam kebahasaan seperti penulisan, kesesuaian tema, ejaan, tanda baca, pilihan kata, kelengkapan makalah, keruntutan, keefektifan kalimat, dan keterpaduan 
paragraf (Musaffak, 2013). Kondisi seperti ini yang menyebabkan penulis pemula akhirnya copy paste karya orang. Hal ini dapat diketahui dengan banyaknya makalah mahasiswa baru PGSD yang hanya copy paste makalah orang yang tersebar dalam blog internet. Terdapat beberapa mahasiswa yang mengaku bahwa makalahnya tidak ambil dari internet melainkan dari buku referensi, akan tetapi meskipun ambil dari referensi makalah yang dibuat tersebut hanya berupa tulisan ulang tanpa memahami informasi dalam bacaan tersebut. Kemampuan dalam mereduksi sumber bacaan juga kurang. Implikasinya adalah ketika presentasi mereka hanya membaca makalah tanpa mengetahui apa makna yang mereka baca.

Berdasarkan hasil wawancara diketahui sebagain besar mahasiswa baru memang merasa kesulitan dalam menulis makalah. Alasan kesulitannya adalah kesulitan mencari referensi, tidak paham teknik penulisan, tidak paham dengan teknik penugasan, tidak paham materi, kurangnya waktu yang diberikan, terbatasnya sarana, malas baca dan kurangnya kerjasama tim. Kondisi semacam ini seharusnya tidak terjadi mengingat referensi sudah banyak tersedia dikampus maupun penelusuran secara online. Berdasarkan analisis hasil angket diketahui bahwa faktor penyebab rendahnya kemampuan menulis makalah mahasiswa baru adalah minat baca yang rendah, pedoman penulisan kurang jelas, rendahnya rasa ingin tahu dan motivasi yang rendah. Sehingga kemampuan menulis juga akan berkurang. Kegiatan membaca dengan menulis tidak dapat dipisahkan harus berjalan beriringan dan saling melengkapi, karena penulis yang baik diawali dari pembaca yang baik (Rahmiati, 2013). Menulis merupakan aktivitas menuangkan gagasan secara sistematis ke dalam bentuk tulisan melalui kegiatan memikirkan, menggali, dan mengembangkan ide (Gereda, 2014). Kunci literasi adalah keterampilan membaca yaitu keterampilan untuk menerjemahkan kalimat kemudian menulis kembali inti dari kalimat tersebut, dan akhirnya konsep dapat dipahami (Zainul, 2018). Tanpa membaca aktivitas dalam pengembangan ide akan sangat terbatas. Pedoman penulisan perlu dibuat agar mahasiswa tidak kebingungan dalam mencari panduan penulisan makalah. Salah satu penelitian menyebutkan bahwa salah satu cara untuk meningkatkan kemampuan menulis makalah adalah dengan membuat modul yang disertai contoh dan latihan agar terbiasa dengan penulisan karya ilmiah yang benar (Awalludin \& Lestari, 2017).

Motivasi yang juga menjadi penyebab rendahnya kualitas makalah yang dibuat mahasiswa. Rendahnya motivasi ditunjukkan dengan anggapan mahasiswa bahwa tugas yang diberikan dosen adalah beban, seharusnya tugas dianggap sebagai kebutuhan dalam pengembangan keilmuan mahasiswa bukan dianggap sebagai beban. Motivasi yang rendah ini menyebabkan mahasiswa asal-asalan dalam menulis makalah, yang penting membuat untuk dikumpulkan sebagai pelengkap tugas kuliah. Rendahnya motivasi ini dapat 
menyebabkan mahasiswa melakukan jalan pintas dengan copy paste karya orang lain. Hal ini sesuai dengan penelitian Pramudiyanti (2018) yang menunjukkan bahwa 100\% makalah mahasiswa hasil copy paste tanpa dilakukan paraphrase.

\section{SIMPULAN}

Berdasarkan hasil penelitian dapat disimpulkan bahwa kemampuan mahasiswa baru dalam menulis makalah masih rendah dengan tingkat plagiasi yang sangat tinggi, sebagian besar mahasiswa baru masih kesulitan dalam menulis makalah, jenis kesulitan yang paling banyak dihadapi yaitu kesulitan mencari referensi dan tidak tahu teknik penulisan makalah, serta faktor penyebab kesulitan menulis makalah adalah rendahnya minat baca, belum ada pedoman penulisan makalah yang jelas, rendahnya rasa ingin tahu dan rendahnya motivasi menulis.

\section{DAFTAR PUSTAKA}

Adhikara, M. A., Handayani, S., Jumono, S., \& Darmansyah, D. (2014). Pelatihan penyusunan artikel publikasi ilmiah. Jurnal Pengabdian Masyarakat Abdimas, 1(1), 41-53. Retrieved from https://ejurnal.esaunggul.ac.id/index.php/ABD/article/viewFile-/1189/1084

Awalludin, \& Lestari, Y. (2017). Pengembangan modul menulis makalah pada mata kuliah pengembangan keterampilan menulis. Jurnal Bindo Sastra, 1(2), 121-130.

Cahyani, I. (2010). Peningkatan kemampuan menulis makalah melalui model pembelajaran berbasis penelitian pada mata kuliah umum Bahasa Indonesia. Sosiohumanika: Jurnal Pendidikan Sains Sosial Dan Kemanusiaan, 3(2), 175-192. Retrieved from http://mindamasjournals.com/index.php/sosiohumanika/article/view/411

Gereda, A. (2014). Kemampuan menulis deskripsi mahasiswa Program Studi Pendidikan Bahasa dan Sastra Indonesia Universitas Musamus. MAGISTRA: Jurnal Keguruan Dan Ilmu Pendidikan, 2(1), 125-137. https://doi.org/10.35724/magistra.v2i1.325

Halidjah, S. (2015). Peningkatan keterampilan menulis karya ilmiah melalui lesson study. BAHTERA : Jurnal Pendidikan Bahasa Dan Sastra, 14(1), 47-54. Retrieved from http://journal.unj.ac.id/unj/index.php/bahtera/article/download/731/635/

Hariri, \& Pradana, A. W. S. (2019). Persepsi mahasiswa akuntansi terhadap pendeteksian plagiasi tugas akhir. JU-Ke (Jurnal Ketahanan Pangan), 3(1), 78-90. Retrieved from http://riset.unisma.ac.id/index.php/JUke/article/view/2719 
Musaffak. (2013). Peningkatan kemampuan menulis makalah mahasiswa pengambil matakuliah Bahasa Indonesia Keilmuan Jurusan Pendidikan Bahasa Inggris FKIP UMM Semester II 2012 dengan Strategi Peta Pikiran. Jurnal Pendidikan Humaniora, 1(4), 354-366. Retrieved from http://journal.um.ac.id/index.php/jph/article/-download/4145/793

Persadha, D. A. K. (2016). Studi kompetensi kemampuan menulis di kalangan mahasiswa. Muaddib: Studi Kependidikan Dan Keislaman, 6(1), 1. https://doi.org/10.24269-/muaddib.v6n1.2016.1-20

Pramudiyanti, P. (2018). Kemampuan mahasiswa Pendidikan Biologi menulis makalah : Sebuah refleksi diri. Jurnal Bioterdidik: Wahana Ekspresi Ilmiah, 6(3). $\quad$ Retrieved from http://jurnal.fkip.unila.ac.id/index.php/JBT/article/viewFile/15538/pdf

Praptanti, I., \& Noorliana, N. (2017). Analisis kemampuan menulis argumentasi pada makalah ilmiah Mahasiswa Farmasi Universitas Muhamadiyah Purwokerto. JSSH (Jurnal Sains Sosial Dan Humaniora), 1(2), 137. https://doi.org/10.30595/jssh.v1i2-.1856

Rahmiati, R. (2013). Problematika mahasiswa dalam menulis karya ilmiah. Jurnal Adabiyah, $\quad 8(2), \quad$ 160-175. $\quad$ https://doi.org/http://journal.uinalauddin.ac.id/index.php/adabiyah/-article/view/363

Rahmiati, R. (2015). Analisis kendala internal mahasiswa dalam menulis karya ilmiah. Al-Daulah: Jurnal Hukum Pidana Dan Ketatanegaraan, 4(2), 327343. https://doi.org/-10.24252/ad.v4i2.1486

Rismen, S. (2015). Analisis kesulitan mahasiswa dalam penyelesaian skripsi di Prodi Pendidikan Matematika STKIP PGRI. Lemma, I(2), 57-62.

Widiastuti, S. (2019). Kemampuan menulis daftar rujukan mahasiswa Program Studi Pendidikan Guru Sekolah Dasar (PGSD) Universitas Islam Balitar (UNISBA). KONSTRUKTIVISME, 11(1), 32-41. Retrieved from https://ejournal.unisbablitar.ac.id/index.php/konstruktivisme/article/downloa d/664/594/

Yanti, N., Suhartono, S., \& Hiasa, F. (2018). Keterampilan menulis akademik mahasiswa S1 Program Studi Pendidikan Bahasa dan Sastra Indonesia FKIP Universitas Bengkulu. Silampari Bisa: Jurnal Penelitian Pendidikan Bahasa Indonesia, Daerah, Dan Asing, 1(1), 1-16. https://doi.org/10.31540/silamparibisa.v1i1.4

Zainul, R. (2018). Studi literasi menggunakan endnote dan aplikasi pembantu (google translator, google cendikia, google sites, chemoffice 2008, elearning, dan snipping Tool). 1-11. https://doi.org/10.31227/osf.io/5ncpe 